\title{
Review: Milking machine settings, teat condition and milking efficiency in dairy cows
}

\author{
M. Odorčić ${ }^{1}$, M. D. Rasmussen², C. O. Paulrud ${ }^{3}$ and R. M. Bruckmaier ${ }^{1 \dagger}$ \\ ${ }^{1}$ Veterinary Physiology, Vetsuisse Faculty, University of Bern, 3001 Bern, Switzerland; ${ }^{2}$ Department of Engineering, Aarhus University, Aarhus C, 8000, Denmark; \\ ${ }^{3}$ DeLaval International $A B$, Tumba 14741, Sweden
}

(Received 8 October 2018; Accepted 7 February 2019)

\begin{abstract}
Because of technical limitations, an impact of machine milking on the teat tissue cannot be avoided. The continuance of this impact during and after milking depends on a variety of factors related to the physiological regulation of milk ejection, as well as the different production systems and milking machine settings. Milking machine settings aim to achieve a high milking performance, that is, short machine-on time at a maximum of milk harvest. However, a high milking performance level is often related to an impact on the teat tissue caused by vacuum or liner compression that can lead to pathological dimensions of congestion of the tissue or hyperkeratosis as a long-term effect. Toward the end of milking a decrease of milk flow rate causes a raise of mouthpiece and teat end vacuum levels and hence an increase of the impact on the teat tissue and the risk of tissue damage. The mechanical stress by the milking machine activates a cascade of cellular mechanisms that lead to an excessive keratin growth and thickening of the keratin layer. Consequently, a complete closure of the teat canal is disabled and the risk of bacterial invasion and intramammary infection increases. Another consequence of high vacuum impact is fluid accumulation and congestion in the tissue of teat tip and teat basis because of an obstruction in venous return. The present review paper provides an overview of the available scientific information to describe the interaction between different levels and types of system vacuum, mouthpiece chamber vacuum, teat end (claw) vacuum, liner pressure, and the risk of short-term and long-term impacts on the teat tissue.
\end{abstract}

Keywords: milking performance, milk flow rate, hyperkeratosis, teat tissue congestion, dairy cow

\section{Implications}

The dairy industry contributes considerably to the nutrition security of an increasing world population. Within the daily work on dairy farms milk harvest is a crucial factor to optimize both performance and product quality. The present paper discusses the potential to optimize the milking routine and machine settings to achieve high milking performance with minimal impact on udder health.

\section{Introductory remarks}

Milk removal in large and small ruminants has changed considerably in the recent decades. With increasing world population and wealth in the industrialized countries the demand for dairy food products has considerably increased. Individual animal performance and herd size has been steadily increased to cover the demand of the consumers, and to ensure an adequate income for the producers. Although modern dairy farms are usually equipped with up-to-date machine milking

\footnotetext{
${ }^{\dagger}$ E-mail: rupert.bruckmaier@vetsuisse.unibe.ch
}

systems, still $33 \%$ to $57 \%$ of the total farm labor refers to the milking process (Edwards et al., 2013). This shows that there is still a need to optimize the milking process to reduce the work load for the milker, with simultaneously minimizing the risk of intramammary infection and the use of antimicrobial substances in food producing animals.

\section{Basic characteristics of the vacuum-based milking machine}

The development of milking machines started in the late 19th century. After a number of non usable types of machines with either teat cannulation, positive pressure on the teat, or continuous vacuum, the two chambered teat cup with cyclic opening and closure of a rubber liner was introduced. Over the decades, countless technical improvements of milking system have increased milking performance, at least partially without increasing the mechanical load on the teat and the risk of intramammary infection. Despite many improvements in milking technology the basic principle of all milking machines on the market is still the same as 100 years ago. 
The teat cup represents the interface between the milking machine and the animal's teat. The goal to copy the rhythmic process of a calf suckling as far as possible during mechanical milking was only partially achieved. There are important technical limitations that make the optimization of machine milking difficult in some respect. Most obvious in contrast to calf suckling, the teat inside the liner is under continuous vacuum, and the vacuum under the teat is subjected to dynamic changes due to the cyclic liner movement and stopand-go of the milk, and due to milk flow dependent vacuum drops. The expected vacuum drop during the course of milking has to be considered in the vacuum settings. A minimum of at least 30 to $32 \mathrm{kPa}$ (kilopascal) is suggested to prevent liner slips and to achieve an optimal liner closure and massage effect during the phases of closed liner (International Organization for Standardization (ISO) note no. 5707, 2007). If the vacuum drop during periods of high milk flow is large (often in high line and mid line systems) the system vacuum must be adjusted to a very high level which can cause an increased impact on the teat tissue when the milk flow ceases at the end of milking (Besier and Bruckmaier, 2016).

\section{Availability of milk and milk ejection}

For an optimal milk removal the continuous availability of milk from cluster attachment until removal is crucial. A transient milking on empty teats as it can happen at delayed milk ejection due to lack of teat preparation, causes an increase of the mouthpiece chamber vacuum and climbing of the teat cups at the beginning of milking. This effect comes along with an increased mechanical load on the teat tissue, thus causing congestion and damage. Pre-stimulation is important in dairy cows because of the low amount of milk available before milk ejection. The proportion of cisternal milk that is immediately available is up to $20 \%$ of the stored milk. Cisternal milk can be close to zero at short intervals between milkings, and toward the end of lactation. The main part of the milk is stored in the alveolar compartment and is only available after tactile teat stimulation and oxytocin release (Bruckmaier, 2001).

For a timely availability of alveolar milk, a proper prestimulation before cluster attachment is recommended. The availability of the alveolar milk at the start of milking causes a positive pressure of the milk inside the teat cistern of up to $8 \mathrm{kPa}$ (Wellnitz et al., 1999) which is beneficial for an optimal refill of the teat during the liner-closed phases. Furthermore, if milking starts after pre-stimulation, milk flow increases steeply after cluster attachment, and the milk flow dependent vacuum drop beneath the teats and in the claw occurs immediately, thus preventing a high vacuum impact on the teat. A combination of reduced vacuum and shortened lineropen phases during the period of low milk flow before milk ejection, can serve as an alternative to pre-stimulation (Neuheuser et al., 2017). Only when the milk flow ceases toward the end of milking, an increase of the claw vacuum up to system vacuum level cannot be prevented (except if the milking system switches again back to low vacuum levels), and high system vacuum levels found in high milk line systems cause a strain on the teat tissue. Early teat cup detachment at a high threshold level is therefore increasingly discussed to prevent the influence of high vacuum on the teat with decreasing flow rate at the end of milking, and to simultaneously reduce the machine-on time and hence increase milking performance. Rasmussen et al. (1992) demonstrated that the required duration of pre-stimulation followed by a latency period vary with respect to breed, number and stage of lactation. Optimal attachment delay of the cluster to omit a decrease in milk yield should not be longer than $90 \mathrm{~s}$ after a sufficient pre-stimulation. In a recent study (Moore-Foster et al., 2018) it was observed that a delay in milk ejection did not result in prolonged milking time which indicates an incomplete udder emptying.

Even a pre-stimulation of $15 \mathrm{~s}$ duration is sufficient to induce oxytocin release but in that case a latency period is required until milk ejection starts to occur (Vetter et al., 2014). Stimulation of the teat is continued by the liner movement throughout milking, and causes oxytocin release and continued milk ejection until cluster detachment (Bruckmaier et al., 1994).

\section{Influence of machine milking on teat condition}

Teat condition changes are classified as short, medium and long-term (Mein et al., 2001). The most important short-term changes caused by circulatory impairment are discolored teats, ringing, swelling and openness of the teat canal. The most important long-term effect is hyperkeratosis. Shortterm changes are reversible from one milking to another or even within a few hours time (Strapák et al., 2018). Careful observation of this short-term changes can be used to avoid long-term effects on the tissue caused by inadequate milking machine settings. Studies have shown that reversibility of machine induced changes varies with different parameters of the teat, specifically cistern diameter and teat canal, which also vary between breeds (Strapák et al., 2018; Martin et al., 2018).

\section{Long-term effects on keratin growth, proliferation and hyperkeratosis}

Although milking machine and clusters are trying to copy the suckling of a calf and the minimum impact it has on the teat integrity, vacuum and pulsations applied onto tissue in the milking procedure, often end up in pathological changes such as teat end congestion or hyperkeratosis. Risk factors on teat tissue integrity have been identified. From the aspect of machine settings this factors can be classified into levels of system vacuum (Hamann and Mein, 1988), level of compressive load (Mein et al., 1987), fluctuations of teat end vacuum (Besier and Bruckmaier, 2016) and mouthpiece chamber vacuum (Penry et al., 2017). The impact of certain factors may be enforced by prolonged milking (Pařilová 
et al., 2011) which can stimulate a disruption of the tissue homeostasis. Evidence suggests a correlation with increasing bacterial colonization of the teat canal and impaired teat tissue condition (Paduch et al., 2012).

One of the studied parameters are the length and diameter of the teat canal (Martin et al., 2018; Strapák et al., 2018); the interface between the mammary gland and the external environment. It functions as a barrier against pathogen invasion. The teat canal is kept closed by a circular smooth muscle based sphincter on its distal end, and is coated with a keratin layer which has a twofold function in prevention of bacterial penetration into the mammary gland. Physically, keratin entraps bacteria, preventing their entry into the mammary gland. Furthermore, keratin contains cationic proteins, xanthine oxidase, long-chain fatty acids which are reported to be bactericidal or bacteriostatic (Capuco et al., 1990). Impaired teat end condition due to excessive keratin growth and thickening of the keratin layer impairs the complete closure of the teat canal and hence increases the risk of bacterial invasion. Thickening of the keratin in the epidermis that surrounds the teat canal (teat-end hyperkeratosis) is linked with the mechanical conditions applied and with the frequency of such milkings (Mein et al., 2003). In the healthy epidermis, keratinocytes continuously differentiate from basal layers, whereas in pathological conditions their growth is activated for proliferation (Freedberg et al., 2001). The difference between keratinocytes differentiated from basal layers and ones that are activated for proliferation are certain proteins that they express in their suprabasal layers (Tomic-Canic et al., 1998). Keratinocytes that differentiate in a regular manner, stop dividing when detaching from the basal membrane due to different keratins $(K 1, K 10)$ that signal terminal differentiation. On the contrary, activated keratinocytes have different proteins $(K 6, K 16)$ in their suprabasal layer associated with hyperproliferation and receptors for infiltrated immune cells. Research suggests that the risk of development of hyperkeratosis increases with lactation number, more days in milk, and teat end shape and size (Neijenhuis et al., 2000; Haverkamp et al., 2017). In both studies the most frequent teat end shape was round, however, the hyperkeratosis score regarding teat end shape differed. Haverkamp et al. (2017) showed a higher hyperkeratosis score with round teat end, while Neijenhuis et al. (2000) suggest that pointed teats are more likely to develop hyperkeratosis. A possible explanation for the different observations may lie in different breeds or milking machine settings. Higher degrees of hyperkeratosis raises a concern because it is associated with a higher frequency of intramammary infection (de Pinho Manzi et al., 2012). Most intramammary infections are caused by the invasion of pathogenic microorganisms through the teat canal, and teats with a higher hyperkeratosis score have been shown to have an elevated microbial load in the teat canal (Paduch et al., 2012).

\section{Factors causing teat congestion}

Teat congestion may arise from accumulation of fluid in the capillaries or in the teat tissue. The level of accumulated fluid in the tissue, can be measured with a spring-loaded caliper (cutimeter) at a pre-defined spring force. This method has been introduced and validated by Hamann and Mein (1988) to observe the effects of various milking methods and vacuum levels on teat condition. Raising the vacuum level from 30 to 50 or $70 \mathrm{kPa}$ resulted in shorter machine-on time but also caused an increase in teat tissue thickness (Hamann and Mein, 1988). Increasing the duration of the liner open phase has been shown to increase peak milk flow rate, machine strip yields and tissue thickness (Hamann and Mein, 1996; Gleeson et al., 2004). A combination of high vacuum levels and long liner open phase increases the potential occurrence of teat-end congestion (Penry et al., 2017). Conversely, lower vacuum causes lower milk flow rates and longer machine-on time, but less impact on the teat tissue (Besier and Bruckmaier, 2016). To relieve the tissue from fluid accumulation and to maintain blood circulation, a minimum d-phase duration of $150 \mathrm{~ms}(15 \%$ of the pulsation cycle) is suggested (Hamann and Mein, 1996). However, if the increase of $b$-phase duration is accompanied with an increase of pulsation rate teat tissue thickness is decreasing (Hamann and Mein, 1996). A shorter d-phase causes an increase in congestion of the teat tissue, as measured by a reduction in teat canal cross sectional area which can be defined as an excess of blood within blood vessels due to an obstruction of venous blood flow (Upton et al., 2016). Liner compression provides massage for the teat and promotes fluid displacement in the tissues that surround the teat canal. The degree of compressive load on the teat during the liner closed phase of one pulsation cycle affects the flow rate of milk in the following cycle (Williams et al., 1981) and seems to be greatest near the teat tip (Mein et al. 1987). The level of compressive load is associated with the occurrence of hyperkeratosis (Mein et al., 2003). If the intensity of liner collapse is constant, the flow curves are repeatable from one cycle to another. Accumulation of fluid in the tissue during prolonged liner open phase (e.g. $>1 \mathrm{~s}$ ) causes a decrease in flow rate and consequently a reduction in milking speed. $\mathrm{A}$ decrease in milk flow rate in individual cycle may be an indicator of edema formation (Williams et al., 1981). The determinative factor of the milk flow rate is the claw vacuum and its different levels during machine milking (Besier and Bruckmaier, 2016). The teat end (claw) vacuum impacts the teat tissue at the start and at the end of milking. At the beginning of milking, higher levels of claw vacuum are due to possible delay in milk ejection and hence bimodality of milk flow, while at the end of milking higher levels of claw vacuum are influenced by a drop of milk flow. Teat end vacuum could have different levels of impact when teat end shape is considered, since lower milk flow rates are found in round and pointed teat ends (Wieland et al., 2017). Furthermore, during the period of low milk flow, mouthpiece chamber vacuum has a distinct effect on the barrel of the teat, and is associated with the risk of barrel congestion and teat cup climbing. Considering variation in the teat size among breeds, individual animals within the same breed (Bobić et al., 2014; Strapák et al., 2018.) and even between 
quarters of the same animal (Tančin et al., 2006), different degrees of interaction between the teat and the liner cannot be avoided. It has been shown that besides vacuum levels the predominant reason for teat tissue thickening and longitudinal stretching of the teat was a too wide liner bore relative to the teat size (Gleeson et al., 2004; Nørstebø et al., 2018). When compared with narrow bore, the use of wide bore liners causes a higher mouthpiece vacuum (O'Callaghan, 1998). Smaller teats were associated with higher mouthpiece chamber vacuum and vice versa. As the teat expands to fill the liner cavity regardless of the barrel width, wide bore liners may also be accompanied with an increase in mouthpiece chamber vacuum ( $0^{\prime}$ Callaghan, 2001). Although higher milk flow is observed with the use of wide bore liners, they cause an increase in teat diameter, canal length, teat wall thickness and decrease in cisternal diameter (Gleeson et al., 2004). Lowering the mouthpiece chamber vacuum is possible with an air admission into the liner (vented liner) which can also promote milk flow (Penry et al., 2017). However, the level of air admission into the liner plays a role in this process. If it is in the range of ISO standard of 4 to $12 \mathrm{l} / \mathrm{min}$ (ISO note 5707, 2007), air admission in general is beneficial, because it optimizes the transport of milk, and minimizes vacuum fluctuations and vacuum drops at high milk flow (Kochman, 2012; Besier and Bruckmaier, 2016). In the same study, data suggests a prolongation in machine on time and lower milk yield by introducing air into the system that was above ISO standard values. Even though vacuum fluctuations beneath the teat end are reduced by letting air into the liner milk quality in terms of free fatty acids may be challenged and increases with more air introduced into the milk stream (Rasmussen et al., 2006). With teats that penetrate deeper into the teat cup at the end of peak flow and beginning of low milk flow rate, a raise in mouthpiece chamber vacuum occurs (Borkhus and Rønningen, 2003). This can be explained with the drop of high intramammary pressure following reduced refill of the teat after which there is a loss in friction between the teat and walls of liner barrel (Reinemann et al., 2001; Borkhus and Rønningen, 2003). Higher mouthpiece chamber vacuum has also been associated with teat-end congestion (Penry et al., 2017) and teat end callosity (Nørstebø et al., 2018). Considering that teat end callosity is observed using standard vacuum settings during the period of low average milk flow rate (Nørstebø et al., 2018), it can be assumed that changes in teat condition are milk flow dependent.

\section{Overmilking}

Overmilking starts when the milk flow to the teat cistern is less than the amount of milk being removed during the lineropen phase (Rasmussen, 2004; Pařilová et al., 2011; Sterrett et al., 2013) and is associated with an elevation in mouthpiece chamber vacuum and fluctuations (Nørstebø et al., 2018). Due to a prolonged period of reduced flow, hyperemia, hemorrhage and edema of epithelial membrane of the teat cistern are starting to occur. The preceding can be explained by the damage of the alveolar epithelium and the epithelial membrane lining the teat cistern due to the continuous friction of its walls. Overmilking causes an increase in the teat surface temperature, thickening of cisternal wall, decrease of the teat diameter and prolongation of the teat canal (Paulrud et al., 2005).

Earlier studies showed that overmilking causes increased hyperkeratosis (Edwards et al., 2013), and a higher intramammary infection rate (Natzke et al., 1982), but no change in teat condition. Previous research indicates that an interaction of overmilking and machine settings is causing a stress to the tissue (Hamann and Mein, 1988; Hillerton et al., 2002; Parilova et al., 2011). A potential explanation is that an impact of certain machine settings on the tissue is merely extended by a prolonged milking. Different liner design was shown to have an effect on the coloration and firmness of the teat and is more pronounced with duration of overmilking (Hillerton et al., 2002). Study by Pařilová et al. (2011.) finds that a combination of higher vacuum level and lower level of cluster detachment leads to a more prominent prolongation of the teat canal and widening of teat diameter. Conversely, almost no effect of prolonged milking in quarters was observed when using a liner that provided a massage on the whole teat (Mein et al., 1986). Another fact that should be considered is that overmilking is milk flow dependent. It occurs at a quarter level, being more pronounced in front than rear quarters because of less available milk and therefore shorter milking time in front than rear quarters, respectively (Tančin et al., 2006). Use of individual quarter pulsation milking system could reduce overmilking and lessen the trauma to the tissue (Sterrett et al., 2013).

\section{Automatic cluster removal}

The mode of operation of the automatic cluster removers is based on vacuum shutdown and removal of the unit after the milk flow reaches a previously defined level (switch point). The removal mechanism of the cluster starts a few seconds before the previously defined level of milk flow is reached (delay time). The optimal flow rate for removal of the cluster unit is still a matter of discussion. It has been shown that early detachment up to a milk flow level of 400 or $600 \mathrm{~g} / \mathrm{min}$ shortens the milking duration without affecting milk yield or milk composition negatively (Edwards et al., 2013; Besier and Bruckmaier, 2016).

In a study where the detachment level was set to $800 \mathrm{~g} / \mathrm{min}$, Magliaro and Kensinger (2005) found a reduction of harvested milk yield. Interestingly, a similar study (Stewart et al., 2002) showed an increase in average milk flow in all the studied herds and a higher milk yield in two out of five herds when higher switch point setting was applied. In higher level of cluster removal $(800 \mathrm{~g} / \mathrm{min})$, lactose, protein and fat content had a tendency to decrease (Ferneborg et al., 2016) which can be better understood with the fact that the milk fraction with the highest nutrient contents remained in the udder (Ontsouka et al., 2003). Regarding tissue condition using different take off levels (Courtot et al. 2009), show that switch point at 
$800 \mathrm{~g} / \mathrm{min}$ lead to a considerable reduction in frequency of tissue thickening or occurrence of hyperkeratosis compared to a detachment level of $200 \mathrm{~g} / \mathrm{min}$. Higher thresholds work well in combination with more frequent milking (Rasmussen, 2004).

\section{Conclusion}

Successful machine milking depends on the interaction of the physiological regulation of milk ejection, and adequate settings of vacuum and pulsation. Moreover, the teat cup liner as the interface between the mammary gland and the milking technology must optimally fit the teat. This goal is only achieved if the teat size and shape does not considerably vary within a dairy herd and thus allow the selection of a specific liner type. The reversibility of teat characteristics such as teat canal length, teat wall diameter or teat tissue thickness to a pre-milking state shortly after milking is required. Recovery of the teat condition is intertwined with the levels of impact of the milking system, which is represented by the teat end vacuum and liner compression, as well as the shape of the liner mouthpiece. While system vacuum and liner compression can be controlled and modified, the level of the impact of mouthpiece chamber vacuum depends on the teat size and shape. Higher levels of claw vacuum will enable faster milking but concomitantly result in a higher risk of teat end impairment during low milk flow at the end of milking. Overall, a suitable compromise needs to be found to maintain a balance between high milking performance and low impact on the teat tissue. For the moment, automatic cluster removal and earlier detachment of the unit at a relatively high milk flow level allows to considerably reduce the influence of higher levels of claw vacuum on the tissue at the end of milking without negatively affecting milk yield or milk composition.

\section{Acknowledgement}

None.

\section{Declaration of interest}

None.

\section{Ethics statement \\ None.}

\section{Software and data repository resources} None.

\section{References}

Besier J and Bruckmaier RM 2016. Vacuum levels and milk-flow-dependent vacuum drops affect machine milking performance and teat condition in dairy cows. Journal of Dairy Science 99, 3096-3102.

Bobić T, Mijić P, Vučković G, Gregić M and Strossmayer JJ 2014. Morphological and milkability breed differences of dairy cows. Mljekarstvo 64, 71-78.
Borkhus $\mathrm{M}$ and Rønningen 0 2003. Factors affecting mouthpiece chamber vacuum in machine milking. Journal of Dairy Research 70, 283-288.

Bruckmaier RM, Schams D and Blum JW 1994. Continuously elevated concentrations of oxytocin during milking are necessary for complete milk removal in dairy cows. Journal of Dairy Research 61, 323-334.

Bruckmaier RM 2001. Milk ejection during machine milking in dairy cows. Livestock Production Science 70, 121-124.

Capuco AV, Wood DL, Bright SA, Miller RH and Bitman J 1990. Regeneration of teat canal keratin in lactating dairy cows. Journal of Dairy Science 73, 1745-1750.

Courtot L, Duouits G and Chapuis D 2009. Réduire le temps de traite par la dépose précoce du faisceau trayeur, en race Montbéliarde (Reducing milking time through an early removal of the cluster, in the Montbéliarde breed). Rencontres autour des Recherches sur les Ruminants 16, 196-196.

Edwards JP, Jago JG and Lopez-Villalobos N 2013. Milking efficiency for grazing dairy cows can be improved by increasing automatic cluster remover thresholds without applying premilking stimulation. Journal of Dairy Science 96, 3766-3773.

Ferneborg S, Stadtmüller L, Pickova J, Wiking L and Svennersten-Sjaunja K 2016. Effects of automatic cluster removal and feeding during milking on milking efficiency, milk yield and milk fat quality. Journal of Dairy Research 83, 180-187. Freedberg IM, Tomic-Canic M, Komine M and Blumenberg M 2001. Keratins and the keratinocyte activation cycle. Journal of Investigative Dermatology 116, 633-640.

Gleeson DE, O'Callaghan EJ and Rath MV. 2004. Effect of liner design, pulsator setting, and vacuum level on measured by ultrasonography. Irish Veterinary Journal $57,289-296$.

Hamann J and Mein GA 1988. Responses of the bovine teat to machine milking: measurement of changes in thickness of the teat apex. Journal of Dairy Research $55,331-338$

Hamann J and Mein GA 1996. Teat thickness changes may provide biological test for effective pulsation. Journal of Dairy Research 63, 179-189.

Haverkamp H, Paduch J-H, Klocke D, Hoedemaker M and Krömker V 2017. Prevalence of teat end hyperkeratosis in lactating dairy cattle and their association with animal variables. International Journal of Environmental and Agriculture Research 3, 75-82.

Hillerton JE, Pankey JW and Pankey P 2002. Effect of over-milking on teat condition. Journal of Dairy Research 69, 81-84.

International Organization for Standardization (ISO 5707) 2007. Milking machine installations - construction and performance. International Organization for Standardization, Geneva, Switzerland.

Kochman AK 2012. Predicting milking performance by controlling air admission at the cluster. In National Mastitis Council, 51st Annual Meeting, 22-24 January 2012, St. Pete Beach, FL, USA, pp. 1-2.

Magliaro AL and Kensinger RS 2005. Automatic cluster remover setting affects milk yield and machine-on time in dairy cows. Journal of Dairy Science 88, 148-153.

Martin LM, Stöcker C, Sauerwein H, Büscher W and Müller U 2018. Evaluation of inner teat morphology by using high-resolution ultrasound: changes due to milking and establishment of measurement traits of the distal teat canal. Journal of Dairy Science 101, 8417-8428.

Mein GA, Neijenhuis F, Morgan WF, Reinemann DJ, Hillerton JE, Baines JR, Ohnstad I, Rasmussen MD, Timmus L, Britt JS and Farsworth R 2001. Evaluation of bovine teat condition in commercial dairy herds: 1 . Non-infectious factors. In Proceedings of the 2nd International Symposium on Mastitis and Milk Quality, 13-15 September 2001, Vancouver, BC, Canada, pp. 362-366.

Mein GA, Williams DMD and Reinemann DJ 2003. Effects of milking on teat end hyperkeratosis: 1 . Mechanical forces applied by the teatcup liner and responses of the teat. In 42nd Annual Meeting of the National Mastitis Council, 26-29 January 2009, Fort Worth, TX, USA, pp. 26-29.

Mein GA, Brown MR and Williams DM 1986. Effects on mastitis of overmilking in conjuction with pulsation failure. Journal of Dairy Research 53, 17-22.

Mein GA, Williams DM and Thiel CC 1987. Compressive load applied by the teatcup liner to the bovine teat. Journal of Dairy Research 54, 327-337.

Moore-Foster R, Norby B, Schewe RL, Thomson R, Bartlett PC and Erskine JR 2018. Herd-level variables associated with delayed milk ejection in Michigan dairy herds. Journal of dairy science 102, 1-10. 
Natzke RP, Everett RW and Bray DR 1982. Effect of overmilking on udder health. Journal of Dairy Science 65, 117-125.

Neuheuser A-L, Belo C and Bruckmaier RM 2017. Technical note: Reduced pulsation chamber vacuum at normal pulsation rate and ratio provides adequate prestimulation to induce oxytocin release and milk ejection while simultaneous milk flow is prevented. Journal of Dairy Science 100, 8609-8613.

Neijenhuis F, Barkhema HW, Hogeveen H and Noordhuizen JPTM 2000. Classification and longitudinal examination of callused teat ends in dairy cows. Journal of Dairy Science 83, 2795-2804.

Nørstebø H, Rachah A, Dalen G, Rønningen 0, Whist AC and Reksen 02018. Milk-flow data collected routinely in an automatic milking system: an alternative to milking-time testing in the management of teat-end condition? Acta Veterinaria Scandinavica 60, 1-9.

O'Callaghan EJ 1998. Machine yield, milking time and cluster. Irish Journal of Agricultural and Food Research 37, 201-207.

O'Callaghan EJ 2001. Influence of liner design on interactions of the teat and liner. Irish Journal of Agricultural and Food Research 40, 169-176.

Ontsouka CE, Bruckmaier RM and Blum JW 2003. Fractionized milk composition during removal of colostrum and mature milk. Journal of Dairy Science 86, 2005-2011.

Paduch JH, Mohr E and Krömker V 2012. The association between teat end hyperkeratosis and teat canal microbial load in lactating dairy cattle. Veterinary Microbiology 158, 353-359.

Pařilová M, Stádník L, Ježková A and Štole L 2011. Effect of milking vacuum level and overmilking on cows' teat characteristics. Acta Universitatis Agriculturae et Silviculturae Mendelianae Brunensis 59, 193-202.

Paulrud CO, Clausen S, Andersen PE and Rasmussen MD 2005. Infrared thermography and ultrasonography to indirectly monitor the influence of liner type and overmilking on teat tissue recovery. Acta Veterinaria Scandinavica 46 , 137-147.

Penry JF, Upton J, Mein GA, Rasmussen MD, Ohnstad I, Thompson PD and Reinemann DJ 2017. Estimating teat canal cross-sectional area to determine the effects of teat-end and mouthpiece chamber vacuum on teat congestion. Journal of Dairy Science 100, 821-827.

de Pinho Manzi M, Nóbrega DB, Faccioli PY, Troncarelli MZ, Menozzi BD and Langoni H 2012. Relationship between teat-end condition, udder cleanliness and bovine subclinical mastitis. Research in Veterinary Science 93, 430-434.

Rasmussen MD 2004. Overmilking and teat condition. In NMC annual meeting proceedings, 01-04 February 2004, Charlotte, NC, USA, pp. 169-175.
Rasmussen MD, Frimer ES, Galton DM and Petersson LG 1992. The influence of premilking teat preparation and attachment delay on milk yield and milking performance. Journal of Dairy Science 75, 2131-2141.

Rasmussen MD, Wiking L, Bjerring M and Larsen HC 2006. Influence of air intake on the concentration of free fatty acids and vacuum fluctuations during automatic milking. Journal of Dairy Science 89, 4596-4605.

Reinemann DJ, Rasmussen MD and Mein GA 2001. Instrument requirements and methods for measuring vacuum in milking machines. American Society of Agricultural Engineers 44, 11-18.

Sterrett AE, Wood CL, McQuerry KJ and Bewley JM 2013. Changes in teat-end hyperkeratosis after installation of an individual quarter pulsation milking system. Journal of Dairy Science 96, 4041-4046.

Stewart S, Godden S, Rapnicki P, Reid D, Johnson a and Eicker S 2002. Effects of automatic cluster remover settings on average milking duration, milk flow, and milk yield. Journal of Dairy Science 85, 818-823.

Strapák P, Szencziová I and Strapáková E 2018. Measurement of teat structures of dairy cow through ultrasonography and examination of morphological changes in teats caused by machine milking. VETERINARIJA IR ZOOTECHNIKA (Vet Med Zoot) 76, 62-69.

Tančin V, Ipema B, Hogewerf P and Mačuhová J 2006. Sources of variation in milk flow characteristics at udder and quarter levels. Journal of Dairy Science 89 978-988.

Tomic-Canic M, Komine M, Freedberg IM and Blumenberg M 1998. Epidermal signal transduction and transcription factor activation in activated keratinocytes. Journal of Dermatological Science 17, 167-181.

Upton J, Reinemann DJ, Penry JF and Thompson PD 2016. A quarter milking analysis device - development and demonstration. Biosystems Engineering 147, 259-264.

Vetter A, Van Dorland HA, Youssef M and Bruckmaier RM 2014. Effects of a latency period between pre-stimulation and teat cup attachment and periodic vacuum reduction on milking characteristics and teat condition in dairy cows. Journal of Dairy Research 81, 107-112.

Wellnitz 0, Bruckmaier RM and Blum JW 1999. Milk ejection and milk removal of single quarters in high yielding dairy cows. Milchwissenschaft 54, 303-309.

Wieland M, Nydam DV and Virkler PD 2017. A longitudinal field study investigating the association between teat-end shape and two minute milk yield, milking unit-on time, and time in low flow rate. Livestock Science 205, 88-97. Williams DM, Mein GA and Brown MR 1981. Biological responses of the bovine teat to milking: Information from measurements of milk flow-rate within single pulsation cycles. Journal of Dairy Research 48, 7-21. 